Research Paper

\title{
Safety and tolerability of deferasirox in pediatric hematopoietic stem cell transplant recipients: one facility's five years' experience of chelation treatment
}

\author{
Natalia Maximova1, Massimo Gregori' ${ }^{2}$, Roberto Simeone ${ }^{3}$, Aurelio Sonzogni ${ }^{4}$, \\ Giulia Boz ${ }^{5}$, Carmen Fucile ${ }^{6}$, Valeria Marini ${ }^{6}$, Antonietta Martelli ${ }^{6}$ and Francesca \\ Mattiolí \\ ${ }^{1}$ Bone Marrow Transplant Unit, Institute for Maternal and Child Health - IRCCS Burlo Garofolo, Trieste, Italy \\ ${ }^{2}$ Department of Pediatric Radiology, Institute for Maternal and Child Health - IRCCS Burlo Garofolo, Trieste, Italy \\ ${ }^{3}$ University of Trieste, Trieste, Italy \\ ${ }^{4}$ Department of Pathology, Ospedale Beato Papa Giovanni XIII, Bergamo, Italy \\ ${ }^{5}$ University of Cagliari, Faculty of Medicine, Cagliari, Italy \\ ${ }^{6}$ Pharmacology and Toxicology Unit, University of Genoa, Genoa, Italy \\ Correspondence to: Maximova Natalia, email: natalia.maximova@burlo.trieste.it \\ Keywords: deferasirox, allogeneic hematopoietic stem cell transplantation (allo-HSCT), pediatric, ductopenia, therapeutic drug \\ monitoring \\ Received: April 05, $2017 \quad$ Accepted: May 23, $2017 \quad$ Published: June 28, 2017 \\ Copyright: Natalia et al. This is an open-access article distributed under the terms of the Creative Commons Attribution License 3.0 \\ (CC BY 3.0), which permits unrestricted use, distribution, and reproduction in any medium, provided the original author and source \\ are credited.
}

\section{ABSTRACT}

42 pediatric patients with iron overload, who underwent liver biopsy and DFX treatment after hematopoietic stem cell transplantation were included in the study group. The patients were divided into two groups diversified according to deferasirox trough plasma concentrations (DFX $C_{\text {trough }}$ ) with cut-off equal to $10 \mathrm{mcg} / \mathrm{mL}$. The average dose of DFX was $25.9 \mathrm{mg} / \mathrm{kg}$ in the DFX $C_{\text {trough }}<10 \mathrm{mcg} / \mathrm{mL}$ group versus $19.2 \mathrm{mg} / \mathrm{kg}$ in the DFX $C_{\text {trough }}>10 \mathrm{mcg} / \mathrm{mL}$ group $(p=0,0003)$. The mean duration of DFX treatment was 135.7 days in the DFX $C_{\text {trough }}<10 \mathrm{mcg} / \mathrm{mL}$ group versus 41.8 days in the DFX $C_{\text {trough }}>10 \mathrm{mcg} / \mathrm{mL}$ group $(p<0.0001)$. The mean tissue iron concentration in the DFX $C_{\text {trough }}<10 \mathrm{mcg} / \mathrm{mL}$ group was $261.9 \mu \mathrm{mol} / \mathrm{g}$ versus $133.4 \mu \mathrm{mol} / \mathrm{g}$ in the DFX $C_{\text {trough }}>10 \mathrm{mcg} / \mathrm{mL}$ group $(p<0.0001) .21$ patients $(100 \%)$ in the DFX $C_{\text {trough }}>$ $10 \mathrm{mcg} / \mathrm{mL}$ group had ductopenia which was complete in $47.6 \%$ of them and severe in 52.4\%. All patients with particularly high $C_{\text {trough }}(>25 \mathrm{mcg} / \mathrm{mL}$ ) were found to have total ductopenia. $\mathbf{9 0 . 5 \%}$ of all deferasirox-related adverse events and $100 \%$ of major adverse events occurred in the DFX $\mathrm{C}_{\text {trough }}>10 \mathrm{mcg} / \mathrm{mL}$ group. In the DFX $\mathrm{C}_{\text {trough }}<10 \mathrm{mcg} / \mathrm{mL}$ group only one patient interrupted chelation therapy versus 16 $(84.2 \%)$ patients in the DFX $C_{\text {trough }}>10 \mathrm{mcg} / \mathrm{mL}$ group. We would recommend a close monitoring in pediatric hematopoietic transplant recipients subjected to deferasiroxbased therapy because we have observed a high incidence of adverse events and discontinuation of chelation treatment.

\section{INTRODUCTION}

Over recent years, allogeneic hematopoietic stem cell transplantation (allo-HSCT) has become an important technique for treating pediatric diseases, especially hematological and oncological disorders and congenital errors. Iron overload (IO), a relatively common but often neglected transplant-related complication, has been associated with poor prognosis in patients undergoing allo-HSCT for onco-hematological diseases [1]. 
Iron is an essential element in humans and its quantity is tightly regulated physiologically; however, because humans lack a mechanism for excretion of iron excess, it can be deposited in end organs, leading to severe dysfunction [2]. Transfused red blood cells (RBCs), both during initial treatment and during the post-transplant period, is considered the main cause of iron overload in HSCT recipients [3]. However, IO in patients with hematological malignancies is multifactorial and not exclusively attributable to the intense transfusion regimen. Intensive cytotoxic therapy before HSCT destroys both bone marrow and neoplastic cells, releasing intracellular iron and consequently increasing free iron concentrations [4]. Furthermore, high dose chemotherapy or total body irradiation, components of conditioning prior to HSCT, can damage hepatic cells, resulting in release of intracellular iron pools and contributing to further increases in iron load [5].

Some studies involving pediatric patients have demonstrated that iron-chelating therapy before allo-HSCT significantly reduces transplant-related mortality (TRM) and increases event-free (EFS) and overall survival (OS) [6]. Given that childhood HSCT survivors have longer life expectancies than adult HSCT recipients, they are likely at higher risk of developing long-term complications such as hepatic fibrosis, and cardiac and endocrine dysfunction. Furthermore, earlier large epidemiologic studies have shown that IO increases to risk of oncological diseases $[7,8]$.

There are few studies regarding the effects of chelation therapy in the post-transplant period in pediatric setting. Additionally, there is a lack of safety and tolerability data about the oral iron chelator deferasirox (DFX) in pediatric patients who have undergone alloHSCT. The largest study that compared the efficacy and safety of once-daily DFX with phlebotomy had 12 and 14 patients, respectively, in these groups [9].

Our retrospective study of one facility's five years' experience of DFX iron chelation in 42 pediatric patients who underwent allo-HSCT shows that this oral chelator must be carefully used in this setting, including implementing therapeutic drug monitoring (TDM).

\section{RESULTS}

Clinical data of the 42 study patients who had undergone oral chelation therapy with DFX in our Institute were retrospectively reviewed and analyzed. Their age range was $2-17$ years.

Most patients (59.5\%) had acute lymphoblastic leukemia (ALL). All study patients had undergone alloHSCT preceded by a myeloablative conditioning regimen.

During the pre-transplantation work-up all patients had undergone an abdominal MRI-based evaluation of iron concentration in the liver, pancreas, spleen, and bone. All patients were found to have IO, which was assessed as moderate in 16 patients (38.1\%) and severe in 26 patients $(61.9 \%)$. The mean number of analyzed organs affected by iron overload was: 3.1 (range: 2-4).

Moreover, all patients had undergone a liver biopsy before leaving the Bone Marrow Transplant Unit. Histological examination demonstrated the presence of ductopenia in 39 (92.8\%) of biopsy samples: 15 patients (33.3\%) were found to have complete ductopenia, 21 $(52.4 \%)$ severe ductopenia and $3(7.7 \%)$ mild ductopenia. None of patients had clinical signs of hepatic or intestinal graft-versus-host-disease (GVHD).

Summaries and associations of baseline characteristics and laboratory values of pediatric patients who had undergone chelation therapy with DFX are shown in Table 1.

\section{Deferasirox treatment}

Minimum steady-state plasma concentrations $\left(\mathrm{C}_{\text {trough }}\right)$ of DFX were measured 24 hours after its administration. Mean DFX $\mathrm{C}_{\text {trough }}$ of the whole study group was $17.4 \mathrm{mcg} / \mathrm{mL}$ (range: $0-95.42 \mathrm{mcg} / \mathrm{mL}$ ). To evaluate safety and tolerability of DFX, patients were divided into two groups: 21 patients with DFX $\mathrm{C}_{\text {trough }}<10 \mathrm{mcg} / \mathrm{mL}$ and 21 with DFX $\mathrm{C}_{\text {trough }}>10 \mathrm{mcg} / \mathrm{mL}(>20 \mu \mathrm{mol} / \mathrm{L})[14]$.

The mean age of patients with DFX $\mathrm{C}_{\text {trough }}<10 \mathrm{mcg} /$ $\mathrm{mL}$ was lower than that of patients with $\mathrm{DFX} \mathrm{C}_{\text {trough }}>10$ $\mathrm{mcg} / \mathrm{mL}[7.8$ vs. 12.5 years $(p=0.0186)]$.

The grade of siderosis was significantly higher in the first group (DFX $\mathrm{C}_{\text {trough }}<10 \mathrm{mcg} / \mathrm{mL}$ ). Mean tissue iron concentrations (MTIC) were calculated for each patient from mean MRI-based LIC, pancreas iron concentration (PIC), spleen iron concentration (SIC) and bone iron concentration (BIC) values. The mean MTIC in the DFX $\mathrm{C}_{\text {trough }}<10 \mathrm{mcg} / \mathrm{mL}$ group was $261.9 \mu \mathrm{mol} / \mathrm{g}$ and in the DFX $\mathrm{C}_{\text {trough }}>10 \mathrm{mcg} / \mathrm{mL}$ group $133.4 \mu \mathrm{mol} / \mathrm{g}(p<$ 0.0001 ).

Fewer organs were affected by IO in patients in the DFX C $_{\text {trough }}>10 \mathrm{mcg} / \mathrm{mL}$ than in those in the DFX C $\mathrm{C}_{\text {trough }}<$ $10 \mathrm{mcg} / \mathrm{mL}$ group (2.3 vs. 3.9 , respectively; $p<0.0001$ ).

All patients $(\mathrm{n}=21)$ in the $\mathrm{DFX} \mathrm{C_{ \text {trough } }}>10 \mathrm{mcg} / \mathrm{mL}$ group had ductopenia diagnosed prior to DFX treatment, which was complete in $47.6 \%$ of them and severe in $52.4 \%$. Ductopenia prior treatment was detected in 18 $(85.7 \%)$ of the 21 patients in the DFX $\mathrm{C}_{\text {trough }}<10 \mathrm{mcg} / \mathrm{mL}$ group. The difference in incidence of severe ductopenia in the two groups was not statistically significant (10 patients vs. $11 ; 47.6 \%$ vs $52.4 \%$ ). However, there was a difference in incidence of complete ductopenia between the two groups: namely, five patients (23.8\%) in the DFX $\mathrm{C}_{\text {trough }}<$ $10 \mathrm{mcg} / \mathrm{mL}$ group versus $10(47.6 \%)$ in the DFX $\mathrm{C}_{\text {trough }}>$ $10 \mathrm{mcg} / \mathrm{mL}$ group.

The mean dose of DFX administered was higher in the DFX $\mathrm{C}_{\text {trough }}<10 \mathrm{mcg} / \mathrm{mL}$ group than in the DFX $\mathrm{C}_{\text {trough }}>10 \mathrm{mcg} / \mathrm{mL}$ group $(25.9 \mathrm{mg} / \mathrm{kg}$ vs. $19.2 \mathrm{mg} / \mathrm{kg} ; p$ $=0,0003$ ). 
Table 1: Baseline characteristics of patients in the study

\begin{tabular}{|c|c|c|c|c|}
\hline Baseline characteristics & Whole cohort & $\begin{array}{c}\text { Moderate iron } \\
\text { overload } \\
(100>\text { LIC }<200 \\
\mu \mathrm{mol} / \mathrm{g})\end{array}$ & $\begin{array}{c}\text { Severe iron } \\
\text { overload } \\
(\mathrm{LIC} \geq 200 \\
\mu \mathrm{mol} / \mathrm{g})\end{array}$ & $p$ Value \\
\hline Patients n (\%) & $42(100)$ & $16(38.1)$ & $26(61.9)$ & - \\
\hline Sex (male/female) & $27 / 15$ & $7 / 9$ & $20 / 6$ & $0.0470 *$ \\
\hline Age, years, median at transplant (range) & $9.7(2-17)$ & $11.8(2-17)$ & $8.6(2-16)$ & $0.0722 * *$ \\
\hline \multicolumn{5}{|l|}{ Underlying disease: $n(\%)$} \\
\hline Acute lymphoblastic leukemia & $25(59.5)$ & $9(36.0)$ & $16(64.0)$ & $0.7570 *$ \\
\hline Acute myeloid leukemia & $6(14.3)$ & $4(66.7)$ & $2(33.3)$ & $0.1798 *$ \\
\hline Severe aplastic anemia & $4(9.5)$ & $1(25.0)$ & $3(75.0)$ & $1.0000 *$ \\
\hline Hemoglobinopathy & $4(9.5)$ & None & $4(9.5)$ & $0.2799 *$ \\
\hline Myelodysplastic syndrome & $2(4.8)$ & $2(100)$ & None & $0.1394 *$ \\
\hline Non-Hodgkin lymphoma & $1(2.4)$ & None & $1(100)$ & $1.0000 *$ \\
\hline \multicolumn{5}{|l|}{ Disease stage: $\mathbf{n}(\%)^{*}$} \\
\hline Early & $14(33.3)$ & $12(85.7)$ & $2(14.3)$ & $<0.0001^{*}$ \\
\hline Intermediate & $9(21.4)$ & $3(33.3)$ & $6(66.6)$ & $0.4585^{*}$ \\
\hline Late & $10(23,8)$ & None & $10(100)$ & $0.0005 *$ \\
\hline \multicolumn{5}{|l|}{ Myeloablative conditioning: n (\%) } \\
\hline Busulfan-based & $19(45.2)$ & $8(42.1)$ & $11(57.9)$ & $0.7527 *$ \\
\hline TBI-based & $23(54.8)$ & $8(34.8)$ & $15(65.2)$ & $0.7527^{*}$ \\
\hline PRBC units received, mean $( \pm \mathrm{SD})$ & $39.4 \pm 17.6$ & $36.2 \pm 12.9$ & $41.8 \pm 20.1$ & $0.2807 * *$ \\
\hline $\begin{array}{l}\text { Ferritin }(\mathrm{ng} / \mathrm{mL}) \text { at beginning of DFX, mean } \\
( \pm \mathrm{SD})^{\S}\end{array}$ & $3597.2 \pm 3505.5$ & $2441.3 \pm 788.4$ & $4070.0 \pm 4289.4$ & $0.1865 * *$ \\
\hline LIC $(\mu \mathrm{mol} / \mathrm{g})$ at beginning of DFX, mean $( \pm \mathrm{SD})$ & $236.2 \pm 59.5$ & $173.4 \pm 12.5$ & $274.8 \pm 40.5$ & $<0.0001 * *$ \\
\hline PIC $(\mu \mathrm{mol} / \mathrm{g})$ at beginning of DFX, mean $( \pm \mathrm{SD})$ & $84.0 \pm 84.7$ & $18.0 \pm 8.1$ & $124.4 \pm 85.4$ & $0.0011 * *$ \\
\hline SIC $(\mu \mathrm{mol} / \mathrm{g})$ at beginning of DFX, mean $( \pm \mathrm{SD})$ & $250.9 \pm 47.1$ & $172.8 \pm 26.3$ & $299.0 \pm 73.8$ & $<0.0001 * *$ \\
\hline $\mathrm{BIC}(\mu \mathrm{mol} / \mathrm{g})$ at beginning of DFX, mean $( \pm \mathrm{SD})$ & $219.5 \pm 91.5$ & $120.9 \pm 43.6$ & $280.2 \pm 50.3$ & $<0.0001 * *$ \\
\hline Histological grade of LIC, mean $( \pm \text { SD })^{\dagger}$ & $3.0 \pm 0.9$ & $2.2 \pm 0.4$ & $3.9 \pm 0.3$ & $<0.0001 * *$ \\
\hline Ductopenia n (\%) & $39(92.8)$ & $16(100)$ & $23(88.5)$ & $0.2753 *$ \\
\hline Organs with iron overload, mean (range) & $3.1(2-4)$ & $2.2(2-3)$ & $3.8(2-4)$ & $<0.0001 * *$ \\
\hline \multicolumn{5}{|l|}{ Degree of ductopenia: $n(\%)$} \\
\hline Ductopenia absent & $3(7.1)$ & None & $3(11.5)$ & $0.2753 *$ \\
\hline Mild ductopenia & $3(7.1)$ & None & $3(11.5)$ & $0.2753 *$ \\
\hline Severe ductopenia & $22(52.4)$ & $8(50,0)$ & $14(53.8)$ & $1.0000 *$ \\
\hline Total ductopenia & $14(33.3)$ & $8(50,0)$ & $6(23.1)$ & $0.0980 *$ \\
\hline
\end{tabular}

LIC, liver iron overload; TBI, total body irradiation; PRBC unit, packed red blood cell unit; SD, standard deviation; DFX, deferasirox; PIC, pancreas iron concentration; SIC, spleen iron concentration; BIC, bone iron concentration.

$\S$ Ferritin normal range 30.0-400.0 ng/mL (male); 13.0-150.0 (female).

tDisease stage was defined according to a previously published classification. This classification was applied to patients with acute leukemia and MDS only [32].

${ }^{\dagger}$ Histological grade of liver iron overload was defined according to a previously published classification [33].

*Fisher's test. **Mann-Whitney test. 
Clinical characteristics and treatment variables according to patient group are shown in Table 2 .

\section{Safety profile of deferasirox}

Drug-related adverse events occurred in 22 patients (52.4\%). Adverse events of Grade 3 or higher occurred in 13 patients, representing $59.1 \%$ of all DFX-related adverse events. Most patients presented more than one adverse event simultaneously. Patients in the DFX C $\mathrm{C}_{\text {trough }}>10 \mathrm{mcg} /$ $\mathrm{mL}$ group accounted for $90.5 \%$ of all adverse events and $100 \%$ of major adverse events.

Adverse events led to discontinuation of DFX treatment in 17 patients $(77.3 \%$ of the 22 patients who experienced adverse events). In the $\mathrm{DFX} \mathrm{C}_{\text {trough }}<10 \mathrm{mcg} /$ $\mathrm{mL}$ group, one of three patients who experienced adverse events stopped chelation therapy versus $16(84.2 \%)$ patients in the DFX C $\mathrm{C}_{\text {trough }}>10 \mathrm{mcg} / \mathrm{mL}$ group. Moreover, in the DFX $\mathrm{C}_{\text {trough }}>10 \mathrm{mcg} / \mathrm{mL}$ group, three patients needed dose reductions to continue their chelation therapy. In this group the most common adverse effects were: fatigue $(73.7 \%)$ and decreased appetite $(68.4 \%)$. The most common organ-specific adverse effects were high bilirubin concentrations $(78.9 \%)$, high creatinine concentrations (78.9\%), anemia $(57.9 \%)$, thrombocytopenia $(52.6 \%)$, high alanine aminotransferase concentrations (52.6\%), and high blood urea nitrogen (52.6\%).

The mean duration of DFX treatment in the whole study group was 88.8 days, the difference between the two groups (135.7 days in the DFX $\mathrm{C}_{\text {trough }}<10 \mathrm{mcg} / \mathrm{mL}$ group vs. 41.8 days in the $\mathrm{DFX} \mathrm{C}_{\text {trough }}>10 \mathrm{mcg} / \mathrm{mL}$ group) being significant.

The safety profile of DFX in pediatric patients undergoing allogeneic HSCT is shown in Table 3.

Table 4 shows Spearman correlation between DFX $\mathrm{C}_{\text {trough }}$, ductopenia (expressed as ratio of number of interlobular bile ducts to number of portal tracts) and MTIC versus clinical characteristics of study patients. Statistically significant correlations (positive or negative) were identified between the duration of the DFX treatment versus MTIC $(\mathrm{r}=0.6954 ; p<0.0001)$ and MTIC versus all laboratory tests performed $(p<0.005)$ except for ferritin $(\mathrm{r}=0.2762 ; p=0.0766)$.

\section{DISCUSSION}

DFX, a potent and highly selective oral iron chelator, was approved in the USA at the end of 2004 and in Europe in 2006. DFX is licensed for use as firstline therapy for chronic blood transfusion-related iron overload in patients aged 2 years and older [15]. The effectiveness of chelation therapy depends on continually adding adequate amounts of the chelator to the body iron pool. Because it has a relatively long half-life of 11-19 h, administration of daily doses of $20 \mathrm{mg} / \mathrm{kg}$ DFX achieves steady-state trough concentrations of approximately 20 $\mu \mathrm{mol} / \mathrm{L}[16]$.

An extensive clinical trial involving more than 1900 patients has demonstrated that deferasirox 20-30 $\mathrm{mg} / \mathrm{kg} /$ day reduces or maintains iron burden in adult and pediatric patients with a variety of transfusiondependent anaemias, including $\beta$-thalassemia, sickle cell disease, aplastic anemia, myelodysplastic syndrome, and miscellaneous rare anemias [17]. Pharmacokinetic studies on patients receiving chelation therapy have demonstrated that mean plasma trough concentrations of DFX in the steady-state of $20 \mu \mathrm{mol} / \mathrm{L}(7.46 \mathrm{mcg} / \mathrm{mL})$ [14]. Only one study has evaluated the safety and tolerability of deferasirox in pediatric patients with transfusiondependent $\beta$-thalassemia major. These patients received a mean DFX dose of $11.3 \mathrm{mg} / \mathrm{kg} /$ day and achieved steadystate plasma $\mathrm{C}_{\max }$ concentrations of $33.5 \mu \mathrm{mol} / 1$ (12.5 $\mathrm{mcg} / \mathrm{mL})$ and $40.1 \mu \mathrm{mol} / \mathrm{L}(14.9 \mathrm{mcg} / \mathrm{mL})$ in children and adolescents respectively [18]. $\mathrm{C}_{\text {trough }}$ is about $25 \%$ of peak concentrations $\left(\mathrm{C}_{\max }\right)[19]$.

The most frequently reported adverse effects in pediatric and adult patients with transfusion-dependent anaemias are generally mild. They include transient gastrointestinal events in $15 \%$, skin rashes in $11 \%$, and mild, dose-dependent increases in serum creatinine in 38\% of patients [15]. Neutropenia, agranulocytosis, worsening anemia, and thrombocytopenia, including fatal events, have been reported, mostly in the patients with preexisting hematologic disorders [20].

Current knowledge about the clinical effects, safety, and tolerability of DFX in pediatric and adult patients with transfusion-dependent anaemias is based on clinical studies conducted on extremely large cohorts. In contrast, there are few data on tolerability and safety of DFX in HSCT recipients.

The most representative research was a multicentric prospective study conducted on 76 adult recipients of allo-HSCT who underwent DFX chelation treatment [21]. Another two studies involved 43 and 23 adult patients who underwent DFX chelation following HSCT [22, 23].

There are almost no data on safety and tolerability of DFX treatment in pediatric recipients of allo-HSCT. The most important pediatric group studied consisted of $12 \beta$-thalassemia major patients with IO aged from 2 to 18 years who had undergone HSCT [24]. Jaekel et al. documented drug-related adverse events in 54 patients (71.1\%), $61 \%$ of which were mild and $36 \%$ moderate in severity. The most common drug-related adverse effect was increase in creatinine concentrations $(26.5 \%)$; thrombocytopenia (5.5\%) and neutropenia were also reported $(2.3 \%)$. Reductions in DFX dose or temporary interruption because of adverse events were required in 65 patients (85.5\%) [21]. Apart from a significant higher number of dose-reductions or interruptions of treatment for severe adverse events, these data are comparable to those reported for patients with transfusion-dependent anemias. 


\begin{tabular}{|c|c|c|c|c|}
\hline & Study group & $\underset{\mathrm{mcg} / \mathrm{ml}}{\mathrm{DFX} \mathrm{\textrm {C } _ { \text { trough } }}<10}$ & $\begin{array}{c}\text { DFX C } C_{\text {trough }}>10 \\
\mathrm{mcg} / \mathrm{ml}\end{array}$ & $p$ Value \\
\hline Patients (\%) & $42(100)$ & $21(50,0)$ & $21(50,0)$ & - \\
\hline Gender (M/F) & $27 / 15$ & $16 / 5$ & $11 / 10$ & $0,1971 *$ \\
\hline Age (years), mean $( \pm$ SD) & $9,7(5,0)$ & $7,8(5,2)$ & $12,5(4,1)$ & $0,0186^{* *}$ \\
\hline BMI $\left(\mathrm{kg} / \mathrm{m}^{2}\right)$, mean $( \pm \mathrm{SD})$ & $18,0(3,2)$ & $18,1(3,5)$ & $18,0(2,8)$ & $0,9899 * *$ \\
\hline LBM (kg), mean ( \pm SD) & $29,8(14,8)$ & $25,9(15,8)$ & $33,7(12,9)$ & $0,0314 * *$ \\
\hline Baseline ferritin $(\mathrm{ng} / \mathrm{ml})$, mean $( \pm$ SD $)$ & $3597,2(3505,5)$ & $4722,3(4653,7)$ & $2472,0(935,9)$ & $0,0681 * *$ \\
\hline Post-treatment ferritin $(\mathrm{ng} / \mathrm{ml})$, mean $( \pm$ SD) & $2287,7(1666,6)$ & $2188,8(1897,4)$ & $2386,7(1439,8)$ & $0,2891 * *$ \\
\hline Organs with IO, mean $( \pm$ SD $)$ & $3,1(0,9)$ & $3,9(0,2)$ & $2,3(0,5)$ & $<0,0001 * *$ \\
\hline MTIC $(\mu \mathrm{mol} / \mathrm{g})$, mean $( \pm$ SD $)$ & $197,6(72,1)$ & $261,9(30,3)$ & $133,4(32,6)$ & $<0,0001 * *$ \\
\hline Presence of ductopenia (\%) & $39(92,8)$ & $18(85,7)$ & $21(100)$ & $0,2317^{*}$ \\
\hline Ductopenia ratio $( \pm \mathrm{SD}) \dagger$ & $0,13(0,4)$ & $0,4(0,5)$ & $0,1(0,0)$ & $0,0013 * *$ \\
\hline Severe ductopenia (\%) & $21(52,4)$ & $10(47,6)$ & $11(52,4)$ & $1,0000^{*}$ \\
\hline Total ductopenia $(\%)$ & $15(33.3)$ & $5(23,8)$ & $10(47,6)$ & $0,1971 *$ \\
\hline DFX dose $(\mathrm{mg} / \mathrm{kg} /$ day $)$, mean $( \pm \mathrm{SD})$ & $22,5(6,0)$ & $25,9(4,7)$ & $19,2(5,4)$ & $0,0003 * *$ \\
\hline Total dose (mg/day), mean $( \pm \mathrm{SD})$ & $753,6(395,7)$ & $754,8(365,9)$ & $752,4(322,1)$ & $0,4771 * *$ \\
\hline Treatment before TDM (days), mean $( \pm$ SD) & $11,2(1,4)$ & $11,3(1,6)$ & $11,0(1,2)$ & $0,6981 * *$ \\
\hline DFX C trough $(\mathrm{mcg} / \mathrm{ml})$, mean $( \pm \mathrm{SD})$ & $17,4(22,2)$ & $3,3(2,3)$ & $32,2(24,1)$ & - \\
\hline
\end{tabular}

DFX, deferasirox; $\mathrm{C}_{\text {trough }}$, measured concentration at the end of a dosing interval at steady state (taken directly before next administration); BMI, body mass index; LBM, lean body mass; SD, standard deviation; IO, iron overload; MTIC, mean tissue iron concentration; TDM, therapeutic drug monitoring.

$\dagger$ Ductopenia is express as the ratio of the number of interlobular bile ducts and number of portal tracts.

*Fisher's test. **Mann Whitney test.

There are no published data on DFX pharmacokinetics in pediatric transplant recipients. There is no evidence that similar chelation therapy should be administered to patients with transfusion-dependent anemias and to HSTC recipients, the latter being subjected to highly aggressive chemotherapy regimens during their treatment. This point is crucial, particularly for pediatric patients with oncohematological disorders.

We performed our study to investigate the high incidence of interruption of DFX treatment for treatmentrelated adverse events. In our institution, DFX treatment is interrupted in $77.3 \%$ of patients, resulting in too short a mean treatment duration (88.8 days).

Evaluation of $\mathrm{C}_{\text {trough }}$ in study patients revealed that a mean $\mathrm{C}_{\text {trough }}$ of $17.4 \mathrm{mcg} / \mathrm{mL}(46.6 \mu \mathrm{mol} / \mathrm{L})$ (range: 0 $\mathrm{mcg} / \mathrm{mL}-95.4 \mathrm{mcg} / \mathrm{mL}[255,8 \mu \mathrm{mol} / \mathrm{l}])$. Concentrations in our cohort were markedly higher than those previously reported (mean $22.5 \mathrm{mg} / \mathrm{kg}$ ), even though the doses of DFX were comparable.

We excluded any pharmacological interference: all patients had received standard immunosuppressive therapy and the anti-infection prophylaxis recommended for HSCT recipients.

We took into consideration the fact that the main DFX elimination pathway does not function optimally in such patients. Direct and indirect evidence indicates that the main pathway of deferasirox metabolism is via hepatic glucuronidation to metabolites M3 (acyl glucuronide) and M6 (2-O-glucuronide) and excretion is predominantly via the feces (78.5-86.9 \% over 7 days) [25]. Unchanged deferasirox in feces most likely includes a small, unabsorbed fraction of the oral dose, deferasirox eliminated via bile or secreted via the gut wall, and deferasirox glucuronides M3 and M6, which are eliminated via the bile and deconjugated in the gut lumen [26].

More than $90 \%$ of patients subjected to allo-HSCT in our institution are found to have from mild to complete ductopenia (unpublished personal data). In our study group, $92.8 \%$ (39 patients) had ductopenia, the percentage being $100 \%$ in the $\mathrm{C}_{\text {trough }}>10 \mathrm{mcg} / \mathrm{mL}$ group. All patients with particularly high $\mathrm{C}_{\text {trough }}(>25 \mathrm{mcg} / \mathrm{mL}[67 \mu \mathrm{mol} / \mathrm{L}])$ were found to have total ductopenia. 
Table 3: Safety profile of deferasirox in pediatric patients with systemic siderosis underwent allogeneic HSCT

\begin{tabular}{|c|c|c|c|c|}
\hline Adverse event, patients (\%) & $\begin{array}{l}\text { Study group } \\
\text { (42 patients) }\end{array}$ & $\begin{array}{c}\text { DFX } \mathrm{C}_{\text {trough }}<10 \\
\mathrm{mcg} / \mathrm{mL} \\
(21 \text { patients })\end{array}$ & $\begin{array}{c}\text { DFX } \mathrm{C}_{\text {trough }}>10 \\
\mathrm{mcg} / \mathrm{mL} \\
\text { (21 patients) }\end{array}$ & p Value \\
\hline \multicolumn{5}{|l|}{ Adverse event, $n(\%)$ : } \\
\hline Any DFX-related adverse event & $22(52.4)$ & $3(14.3)$ & $19(90.5)$ & $0.0001 *$ \\
\hline Any Grade 1-2 adverse event ${ }^{\#}$ & $9(40.9)$ & $3(100)$ & $6(28.6)$ & $0.4537^{*}$ \\
\hline Any Grade 3-4 adverse event ${ }^{\#}$ & $13(59.1)$ & None & $13(61.9)$ & $0.0001 *$ \\
\hline Death (Grade 5) & None & None & None & None \\
\hline Adverse event resulting in discontinuation & $17(77.3)$ & $1(33.3)$ & $16(84.2)$ & $0.0001 *$ \\
\hline Dose reduction & $3(13.6)$ & None & $3(15.8)$ & $0.2317 *$ \\
\hline \multicolumn{5}{|l|}{ DFX-related events: } \\
\hline \multicolumn{5}{|l|}{ General disorders, $n$ (\%) } \\
\hline Fatigue & $14(63.6)$ & None & $14(73.7)$ & $0.0001^{*}$ \\
\hline Decreased appetite & $14(63.6)$ & $1(33.3)$ & $13(68.4)$ & $0.0002 *$ \\
\hline Nausea, vomiting & $10(45.5)$ & $1(33.3)$ & $9(47.4)$ & $0.0089 *$ \\
\hline Gastrointestinal pain & $9(40.9)$ & $2(66.7)$ & $7(36.8)$ & $0.1300^{*}$ \\
\hline Acidosis & $3(13.6)$ & None & $3(15.8)$ & $0.2317^{*}$ \\
\hline \multicolumn{5}{|l|}{ Investigations, mean $( \pm S D)$} \\
\hline Neutrophils (count $/ \mu \mathrm{L}$ ) & $2453 \pm 1623$ & $2993 \pm 1563$ & $1914 \pm 1532$ & $0.0091 * *$ \\
\hline Hemoglobin $(\mathrm{g} / \mathrm{dL})$ & $10.5 \pm 1.6$ & $11.2 \pm 1.2$ & $9.9 \pm 1.8$ & $0.0607 * *$ \\
\hline Platelets $\left(\mathrm{x} 10^{3} / \mu \mathrm{L}\right)$ & $156 \pm 102$ & $181 \pm 79$ & $132 \pm 118$ & $0.0295 * *$ \\
\hline Alanine aminotransferase (U/L) & $52.8 \pm 56.4$ & $30.0 \pm 15.4$ & $75.6 \pm 72.1$ & $0.0643 * *$ \\
\hline Aspartate aminotransferase $(\mathrm{U} / \mathrm{L})$ & $38.9 \pm 40.1$ & $25.6 \pm 7.7$ & $52.1 \pm 53.5$ & $0.0495 * *$ \\
\hline Gamma-glutamyltransferase (U/L) & $32.2 \pm 32.5$ & $22.9 \pm 9.6$ & $41.6 \pm 43.5$ & $0.5372 * *$ \\
\hline Blood bilirubin (mg/dL) & $0.8 \pm 0.6$ & $0.46 \pm 0.26$ & $1.09 \pm 0.64$ & $0.0005 * *$ \\
\hline Blood direct bilirubin (mg/dL) & $0.3 \pm 0.2$ & $0.15 \pm 0.05$ & $0.40 \pm 0.16$ & $<0.0001 * *$ \\
\hline Blood creatinine $(\mathrm{mg} / \mathrm{dL})$ & $0.7 \pm 0.4$ & $0.4 \pm 0.3$ & $0.9 \pm 0.4$ & $0.0002 * *$ \\
\hline Blood urea nitrogen $(\mathrm{mg} / \mathrm{dL})$ & $35.8 \pm 17.5$ & $25.7 \pm 9.9$ & $45.9 \pm 17.8$ & $0.0002 * *$ \\
\hline DFX treatment duration (days), mean $( \pm \mathrm{SD})$ & $88.8 \pm 82.9$ & $135.8 \pm 56.8$ & $41.8 \pm 79$ & $<0.0001^{* *}$ \\
\hline
\end{tabular}

"Adverse events were graded according to the National Cancer Institute's Common Terminology Criteria for adverse events, version 4.02 .

HSCT, hematopoietic stem cell transplantation; DFX, deferasirox.

*Fisher's test. **Mann-Whitney test.

We demonstrated a statistically significant inverse correlation between ductopenia ratio and $\mathrm{C}_{\text {trough }}(\mathrm{r}=$ $-0.4301, p=0.0044)$ and positive correlation between ductopenia ratio and duration of DFX treatment $(\mathrm{r}=$ $0.4299, p=0.0044)$.

Biliary tract injury leading to reduced elimination of the drug is considered to be the main cause of chelator overload. However, a possible secondary cause is the small body iron pool in some patients undergoing alloHSCT. DFX has a high affinity and specificity for iron. Two DFX molecules are required to form a stable complex with each iron $\left(\mathrm{Fe}^{3+}\right.$ ) atom [27]. In the $\mathrm{C}_{\text {trough }}>10 \mathrm{mcg} / \mathrm{mL}$ group, the mean tissue iron concentration was half that in the $\mathrm{C}_{\text {trough }}<10 \mathrm{mcg} / \mathrm{mL}$ group (133.4 vs. $261.9 \mu \mathrm{mol} / \mathrm{g}$, respectively). Our data revealed a significant inverse correlation between MTIC and DFX C $\mathrm{trough}_{\text {( }}(\mathrm{r}=-0.9159, p$ 
Table 4: Spearman correlation between DFX Ctrough, ductopenia ratio, and MTIC versus clinical variables

\begin{tabular}{|c|c|c|c|c|c|c|}
\hline \multirow[t]{2}{*}{ Patients, $n=42$} & \multicolumn{2}{|c|}{$\begin{array}{c}\text { DFX C } \\
\mu \mathrm{g} / \mathrm{mL} \\
\end{array}$} & \multicolumn{2}{|c|}{$\begin{array}{c}\text { Ductopenia, } \\
\text { ratio } \dagger\end{array}$} & \multicolumn{2}{|c|}{$\begin{array}{l}\text { MTIC, } \\
\mu \mathrm{mol} / \mathrm{g}\end{array}$} \\
\hline & $\mathbf{r}$ & $\mathbf{p}$ & $\mathbf{r}$ & $\mathbf{p}$ & $\mathbf{r}$ & $\mathbf{p}$ \\
\hline DFX treatment duration (days) & -0.6932 & $<0.0001$ & 0.4299 & 0.0044 & 0.6954 & $<0.0001$ \\
\hline DFX Ctrough $(\mu \mathrm{g} / \mathrm{mL})$ & - & - & -0.4301 & 0.0044 & -0.9159 & $<0.0001$ \\
\hline Ferritin $(\mathrm{ng} / \mathrm{mL})$ & -0.1787 & 0.2573 & -0.2334 & 0.1369 & 0.2762 & 0.0766 \\
\hline Organs with IO (n) & 0.0900 & 0.5706 & -0.4059 & 0.0076 & 0.9264 & $<0.0001$ \\
\hline MTIC $(\mu \mathrm{mol} / \mathrm{g})$ & -0.9159 & $<0.0001$ & 0.4649 & 0.0019 & - & - \\
\hline Neutrophil (count $/ \mu L)$ & -0.4203 & 0.0056 & 0.3451 & 0.0252 & 0.4345 & 0.0040 \\
\hline Hemoglobin (g/dL) & -0.3031 & 0.0510 & 0.2801 & 0.0723 & 0.3216 & 0.0378 \\
\hline Platelets $\left(\times 10^{3} / \mu \mathrm{L}\right)$ & -0.3680 & 0.0165 & 0.2340 & 0.1357 & 0.3296 & 0.0330 \\
\hline $\operatorname{AST}(\mathbf{U} / \mathbf{L})$ & 0.4412 & 0.0034 & -0.4725 & 0.0016 & -0.4168 & 0.0060 \\
\hline $\operatorname{ALT}(\mathbf{U} / \mathbf{L})$ & 0.4005 & 0.0086 & -0.3660 & 0.0171 & -0.3869 & 0.0114 \\
\hline Blood total bilirubin (mg/dL) & 0.5960 & $<0.0001$ & -0.3532 & 0.0217 & -0.3768 & 0.0139 \\
\hline Blood direct bilirubin (mg/dL) & 0.7433 & $<0.0001$ & -0.4707 & 0.0016 & -0.5231 & 0.0004 \\
\hline Clearance creatinine $\left(\mathrm{mL} / \mathrm{min} / \mathrm{m}^{2}\right)$ & -0.7196 & $<0.0001$ & 0.5223 & 0.0004 & 0.6729 & $<0.0001$ \\
\hline
\end{tabular}

DFX, deferasirox; MTIC, mean tissue iron concentration; IO, iron overload; AST, aspartate aminotransferase; ALT, alanine aminotransferase.

$\dagger$ Ductopenia is expressed as the ratio of the number of interlobular bile ducts to number of portal tracts.

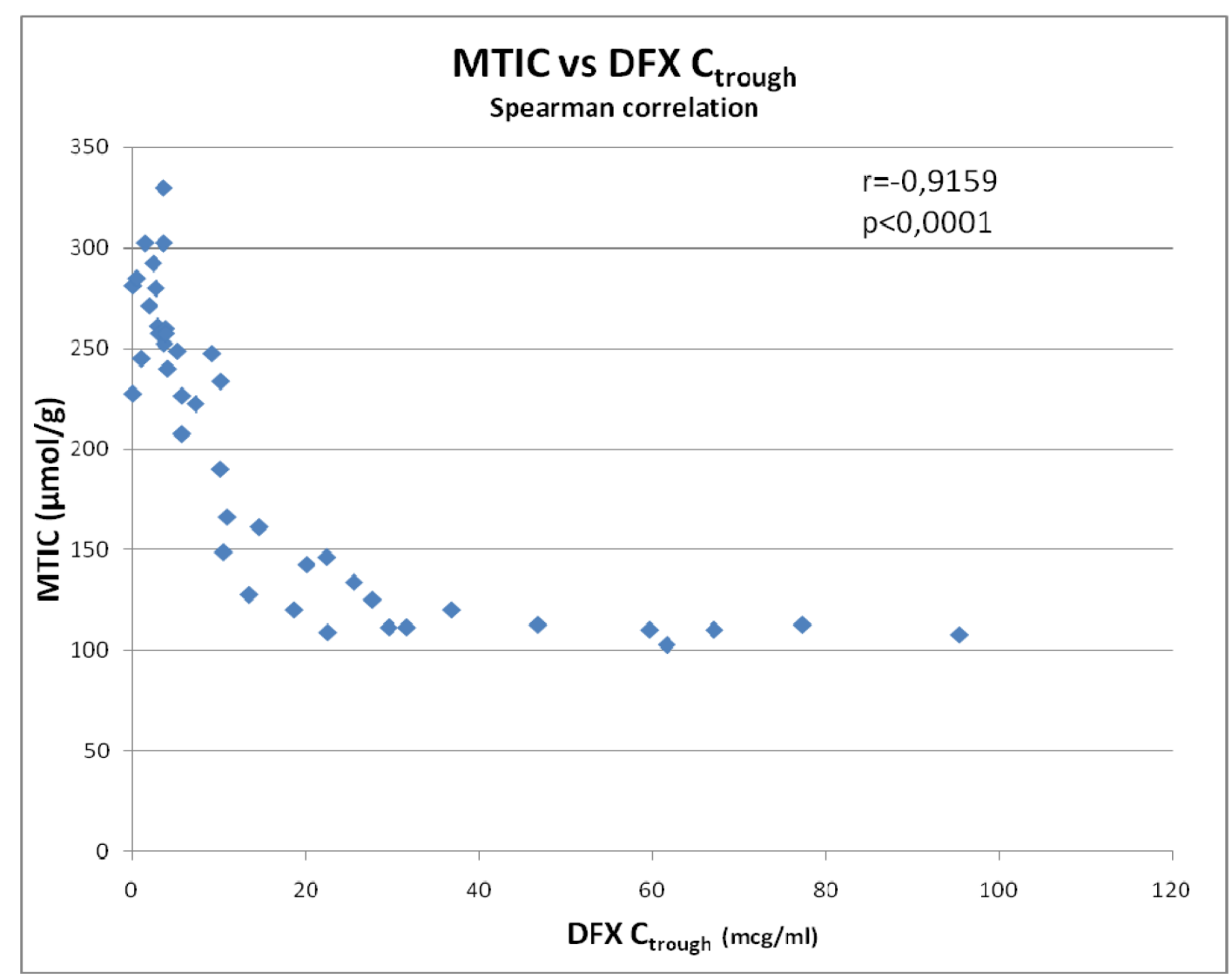

Figure 1: Relationship between mean tissue iron concentration (MTIC) and deferasirox minimum plasma concentration $\left(\mathrm{C}_{\text {trough }}\right)$. 
$<0.0001)$ and positive correlation between DFX treatment duration and MTIC $(r=0.6954 ; p<0.0001)$. Figure 1 shows the strong inverse relationship between MTIC and DFX $\mathrm{C}_{\text {trough. }}$

We found no significant correlation between MTIC and DFX $\mathrm{C}_{\text {trough }}$ and serum ferritin concentrations (Table 4). However, it has been well established that high serum ferritin concentrations are not specific for iron overload and do not provide an exact estimation of body iron stores [28, 29]. Serum ferritin has been shown to be only modestly correlated with iron overload in allogeneic HCT recipients $[30,31]$.

Patients with mild IO and few involved organs likely have fewer iron atoms in parenchymal tissues and therefore fewer iron atoms to bond with DFX molecules. In such patients who also have ductopenia, the excess free DFX molecules cannot be effectively eliminated, leading to accumulation of free DFX molecules in their blood.

In contrast, patients with severe IO likely have more available iron atoms and when too few of them are eliminated, as in patients with mild IO, the circulating DFX consist of both free and chelated components, the latter not being recognized by current detecting methods.

The limitations of this investigation include the retrospective, nonrandomized design and small patient cohort. Because the study was retrospective, we could not perform assess the participants' genetic characteristic. DFX glucuronidation is controlled by the UDPglucuronosyltransferase 1A subfamily (UGT1A1 and, to a lesser extent, UGT1A3). UGT1A1 polymorphism has been recognized as an important element in drug tolerance because it increases the risk of toxicity of drugs metabolized via glucuronidation [11].

Pre-transplant evaluation of systemic iron overload allows an early introduction of chelation therapy. This treatment may be particularly useful in preventing the pre-transplant onset or worsening of siderosis in patients subjected to intense chemotherapy regimens for their primary disease.

Based on our results, we would recommend the DFX starting dose of $10 \mathrm{mg} / \mathrm{kg} /$ day with close monitoring of pediatric HSCT recipients in order to reduce the incidence of adverse events and the rate of discontinuation of the chelation treatment. DFX treatment (dose: 20-30 $\mathrm{mg} / \mathrm{kg} /$ day), ordinarily recommended for patients with transfusion-dependent anemias, should be considered in patients without ductopenia only. The sample size of our study is too small: further research is needed to determine the role of ductopenia and of iron overload in the incidence of adverse events during DFX therapy in this specific setting.

\section{MATERIALS AND METHODS}

This single center, retrospective, cohort study was conducted at the Bone Marrow Transplant Unit of Institute for Research in Maternal and Child Health IRCCS Burlo Garofolo in Trieste, Italy. The design and execution of this study were approved by the Ethics Committee of our Institute (Reference no. 1105/2015). Because of the retrospective nature of the study, the requirement to obtain informed consent was waived. Written informed consent for the use of clinical data for research was obtained for all patients at the time of admission to the Transplant Unit.

\section{Patients}

Medical records of all pediatric patients who had undergone allo-SCT in our Institute from January 2011 to June 2016 were retrospectively reviewed and analyzed. Patients without IO, patients with IO who not received any chelation treatment or who had undergone chelation therapy with agents other than DFX, patients who had no plasma samples available for TDM, and those who had not undergone percutaneous liver biopsy were excluded.

The inclusion criteria were as follows: age under 18 years at the time of HSCT, follow-up of survivors for more than six months, presence of IO documented by magnetic resonance imaging (MRI) quantification of liver iron concentration (LIC) performed before transplantation, chelation treatment in post-transplant period with DFX, histological evaluation of hepatic tissue performed after HSCT for diagnostic reasons, and plasma sample(s) collected during DFX treatment and stored at $-80^{\circ} \mathrm{C}$ available for TDM. Application of the exclusion and inclusion criteria resulted in a study cohort comprising 42 patients. Baseline characteristics of these patients are listed in Table 1.

\section{Chelation treatment}

All patients in the study group had from moderate to severe LIC and had undergone oral chelation therapy with deferasirox (Exjade, Novartis, Basel, Switzerland). This treatment begun after discharge from the Transplant Unit and was performed until LIC values had normalized or DFX-related side effects had been identified. For patients who experienced side effects we have considered either dose reduction or discontinuation as reported in the Summary of product characteristics. Discontinuation of DFX treatment criteria were: hematologic involvement (thrombocytopenia, anemia, neutropenia), hepatic or renal impairment or poor compliance because of nausea and vomiting.

\section{TDM of DFX plasma concentrations}

Deferasirox plasma concentrations (C-DFX) were determined by high performance liquid chromatography (HPLC) assay, as previously described and validated $[10,11]$. Plasma samples were processed by liquidliquid extraction using methanol. Sample analysis (100 $\mathrm{mcL}$ ) was performed using a $150 \times 4.6 \mathrm{~mm}$ Alltima 
C18 Column (Alltech, Casalecchio di Reno BO, Italy) at room temperature. The mobile phase consisted of a mixture of disodium hydrogen phosphate $(0.05 \mathrm{M})$ and tetrabutylammonium hydrogen sulfate $(0.01 \mathrm{M})$ acetonitrile-methanol (42: 12: $46, \mathrm{v} / \mathrm{v} / \mathrm{v})$; the elution being carried out at flow rate of $1.3 \mathrm{~mL} /$ minute and DFX monitored at a wavelength of $295 \mathrm{~nm}$. The retention time was about $15 \mathrm{~min}$. Calibration points were constructed using a pool of blank human plasma spiked with DFX at concentrations ranging from 1.25 to $60 \mathrm{mcg} / \mathrm{mL}$ and the results analyzed by linear regression. The calibration curves of DFX were linear from 1.25 to $60 \mathrm{mcg} / \mathrm{mL}$, resulting in a correlation coefficient o $\mathrm{r}^{2}=0.999$.

\section{Histological examination of liver tissue}

Histological examination was focused on evaluating the degree of ductopenia. Ductopenia is a one of the histological features traditionally linked to the diagnosis of hepatic graft versus host disease [12] and is expressed as the ratio of the number of interlobular bile ducts to number of portal tracts. Mild ductopenia was diagnosed when $>50 \%$ of interlobular bile ducts in all portal tracts of the biopsy sample were present, severe ductopenia when $\leq 50 \%$ interlobular bile ducts were present, and total ductopenia when no interlobular bile ducts were present. IO in liver specimens was graded as Grade 0 to Grade 4 according to Scheuer's classification by examination of Perls' histochemically-stained sections [13].

\section{Statistical analysis}

Continuous variables are expressed as mean \pm standard deviation (SD) and categorical variables as frequency, absolute value or percentage. Results were compared by non-parametric statistics; Spearman's rank correlation coefficient was used to assess the relationship between all continuous variables and the clinical variable of biliary ductopenia and the Mann-Whitney $U$-test to compare unpaired data in different groups of patients with or without severe ductopenia or different DFX plasma concentrations. Fisher's exact test was performed to assess the strength of association between categorical variables. All statistical tests were two-sided, with $\mathrm{p}$ values $<0.05$ considered to denote statistical significance. Statistical analysis was performed using WinStat software (v.2012.1, R. Fitch).

\section{ACKNOWLEDGMENTS}

The study did not provide any source of funding by the Sponsor.

\section{CONFLICTS OF INTEREST}

Natalia Maximova, Massimo Gregori, Roberto Simeone, Aurelio Sonzogni, Giulia Boz, Carmen Fucile,
Valeria Marini, Antonietta Maria Martelli, Francesca Mattioli declare that they have no conflicts of interest.

\section{REFERENCES}

1. Majhail NS, Lazarus HM, Burns LJ. Iron overload in hematopoietic cell transplantation. Bone Marrow Transplant. 2008; 41:997-1003.

2. Poggiali E, Cassinerio E, Zanaboni L, Cappellini MD. An update on iron chelation therapy. Blood Transfus. 2012; 10:411-422.

3. Reddy K, Eng J, Carlson C, Ginsberg J, Fish J. Impact of transfusional support for childhood cancer - peering behind the iron curtain: (Poster 119). Pediatr Blood Cancer. 2011; 56:908.

4. Evens AM, Mehta J, Gordon LI. Rust and corrosion in hematopoietic stem cell transplantation: the problem of iron and oxidative stress. Bone Marrow Transplant. 2004; 34:561-571.

5. Gordon LI, Brown SG, Tallman MS, Rademaker AW, Weitzman SA, Lazarus HM, Kelley CH, Mangan C, Rubin H, Fox RM, Creger RJ, Winter JN. Sequential changes in serum iron and ferritin in patients undergoing high-dose chemotherapy and radiation with autologous bone marrow transplantation: possible implications for treatment related toxicity. Free Radic Biol Med. 1995; 18:383-389.

6. Lee JW, Kang HJ, Kim EK, Kim H, Shin HY, Ahn HS. Effect of iron overload and iron- chelating therapy on allogeneic hematopoietic SCT in children. Bone Marrow Transplantation. 2009; 44:793-797.

7. Mainous AG III, Wells BJ, Koopman RJ, Everett CJ, Gill JM. Iron, lipids, and risk of cancer in the Framingham Offspring cohort. Am J Epidemiol. 2005; 161:1115-1122.

8. Stevens RG, Jones DY, Micozzi MS, Taylor PR. Body iron stores and the risk of cancer. N Engl J Med. 1988; 319:1047-1052.

9. Inati A, Kahale M, Sbeiti N, Cappellini MD, Taher AT, Koussa S, Nasr TA, Musallam KM, Abbas HA, Porter JB. One-year results from a prospective randomized trial comparing phlebotomy with deferasirox for the treatment of iron overload in pediatric patients with thalassemia major following curative stem cell transplantation. Pediatr Blood Cancer. 2017; 64:188-196.

10. Rouan MC, Marfil F, Mangoni P, Séchaud R, Humbert $\mathrm{H}$, Maurer G. Determination of a new oral iron chelator, ICL670, and its iron complex in plasma by highperformance liquid chromatography and ultraviolet detection. J Chromatogr B. 2001; 755:203-213.

11. Mattioli F, Puntoni M, Marini V, Fucile C, Milano G, Robbiano L, Perrotta S, Pinto V, Martelli A, Forni GL. Determination of deferasirox plasma concentrations: do gender, physical and genetic differences affect chelation efficacy? Eur J Haematol. 2015; 94:310-317.

12. Duarte RF, Delgado J, Shaw BE, Wrench DJ, Ethell M, Patch D, Dhillon AP, Mackinnon S, Potter MN, Quaglia AF. 
Histologic features of the liver biopsy predict the clinical outcome for patients with graft-versus-host disease of the liver. Biol Blood Marrow Transplant. 2005 Oct;11:805-813.

13. MacSween RNM, Anthony PP, Scheuer PJ (eds.). Pathology of the liver. $2^{\text {nd }}$ edition. Churchill Livingstone, Edinburgh. 1987; 257-272.

14. Piga A, Galanello R, Forni GL, Cappellini MD, Origa R, Zappu A, Donato G, Bordone E, Lavagetto A, Zanaboni L, Sechaud R, Hewson N, Ford JM, et al. Randomized phase II trial of deferasirox (Exjade, ICL670), a once-daily, orallyadministered iron chelator, in comparison to deferoxamine in thalassemia patients with transfusional iron overload. Haematologica. 2006; 91:873-880.

15. Novartis Pharmaceuticals. EXJADE (deferasirox) US prescribing information; 2013.

16. Porter JB. Deferasirox - current knowledge and future challenges. Ann N Y Acad Sci. 2010; 1202:87-93.

17. Galanello R, Campus S, Origa R. Deferasirox: pharmacokinetics and clinical experience. Expert Opin Drug Metab Toxicol. 2012; 8:123-134.

18. Galanello R, Piga A, Forni GL, Bertrand Y, Foschini ML, Bordone E, Leoni G, Lavagetto A, Zappu A, Longo F, Maseruka H, Hewson N, Sechaud R, Belleli R, et al. Phase II clinical evaluation of deferasirox, a once-daily oral chelating agent, in pediatric patients with b- thalassemia major. Haematologica. 2006; 91:1343-1351.

19. Galanello R, Origa R. Once-daily oral deferasirox for the treatment of transfusional iron overload. Expert Rev Clin Pharmacol. 2008; 1:231-240.

20. Cappellini MD, Porter JB, El-Beshlawy A, Li CK, Seymour JF, Elalfy M, Gattermann N, Giraudier S, Lee JW, Chan LL, Lin KH, Rose C, Taher A, et al. Tailoring iron chelation by iron intake and serum ferritin trends: the prospective multicenter EPIC study of deferasirox in 1744 patients with various transfusion-dependent anemias. Haematologica. 2010; 95:557-566.

21. Jaekel N, Lieder K, Albrecht S, Leismann O, Hubert K, Bug G, Kröger N, Platzbecker U, Stadler M, de Haas K, Altamura S, Muckenthaler MU, Niederwieser D, Al-Ali HK. Efficacy and safety of deferasirox in non-thalassemic patients with elevated ferritin levels after allogeneic hematopoietic stem cell transplantation. Bone Marrow Transplant. 2016:51; 89-95.

22. Sivgin S, Baldane S, Akyol G, Keklik M, Kaynar L, Kurnaz F, Pala C, Zararsiz G, Cetin M, Eser B, Unal A. The oral iron chelator deferasirox might improve survival in allogeneic hematopoietic cell transplant (alloHSCT) recipients with transfusional iron overload. Transfus Apher Sci. 2013; 49:295-301.

23. Sivgin S, Eser B, Bahcebasi S, Kaynar L, Kurnaz F, Uzer E. Efficacy and safety of oral deferasirox treatment in the posttransplant period for patients who have undergone allogeneic hematopoietic stem cell transplantation (alloHSCT). Ann Hematol. 2012; 91:743-749.

24. Inati A, Kahale M, Sbeiti N, Cappellini MD, Taher AT, Koussa S, Koussa S, Nasr TA, Musallam KM, Abbas HA, Porter JB. One-year results from a prospective randomized trial comparing phlebotomy with deferasirox for the treatment of iron overload in pediatric patients with thalassemia major following curative stem cell transplantation. Pediatr Blood Cancer. 2017; 64:188-196.

25. Waldmeier F, Bruin GJ, Glaenzel U, Hazell K, Sechaud R, Warrington S, Porter JB. Pharmacokinetics, metabolism, and disposition of deferasirox in beta-thalassemic patients with transfusion-dependent iron overload who are at pharmacokinetic steady state. Drug Metab Dispos. 2010; 38:808-816.

26. Tanaka C. Clinical pharmacology of deferasirox. Clin Pharmacokinet. 2014; 53:679-694.

27. Cappellini MD, Taher A. Long-term experience with deferasirox (ICL670), a once-daily oral iron chelator, in the treatment of transfusional iron overload. Expert Opin Pharmacother. 2008; 9:2391-2402.

28. Olivieri NF, Brittenham GM. Iron-chelating therapy and the treatment of thalassemia. Blood. 1997; 89:739-761.

29. Brittenham GM, Griffith PM, Nienhuis AW, McLaren CE, Young NS, Tucker EE, Allen CJ, Farrell DE, Harris JW. Efficacy of deferoxamine in preventing complications of iron overload in patients with thalassemia major. N Engl J Med. 1994; 331:567-573.

30. Majhail NS, DeFor T, Lazarus HM, Burns LJ. High prevalence of iron overload in adult allogeneic hematopoietic cell transplant survivors. Biol Blood Marrow Transplant. 2008; 14:790-794.

31. Armand P, Sainvil MM, Kim HT, Rhodes J, Cutler C, Ho VT, Koreth J, Alyea EP, Neufeld EJ, Kwong RY, Soiffer RJ, Antin JH. Does iron overload really matter in stem cell transplantation? Am J Hematol. 2012; 87:569-572.

32. Gratwohl A, Stern M, Brand R, Apperley J, Baldomero H, de Witte T, Dini G, Rocha V, Passweg J, Sureda A, Tichelli A, Niederwieser D; European Group for Blood and Marrow Transplantation and the European Leukemia Net. Risk score for outcome after allogeneic hematopoietic stem cell transplantation: a retrospective analysis. Cancer. 2009; 115:4715-4726.

33. Maximova N, Gregori M, Zennaro F, Sonzogni A, Simeone R, Zanon D. Hepatic gadolinium deposition and reversibility after contrast agent-enhanced MR imaging of pediatric hematopoietic stem cell transplant recipients. Radiology. 2016; 281:418-426. 